\title{
Distinct pigmentation and trophic modes in Beggiatoa from hydrocarbon seeps in the Gulf of Mexico
}

\author{
Roxanne Nikolaus ${ }^{1}$, James W. Ammerman ${ }^{2}$, Ian R. MacDonald ${ }^{3, *}$ \\ ${ }^{1}$ US Commission on Ocean Policy, 1120 20th Street NW, Suite 200 North, Washington, DC 20036, USA \\ ${ }^{2}$ Institute of Marine and Coastal Sciences, Rutgers University, 71 Dudley Road, New Brunswick, New Jersey 08901-8521, USA \\ ${ }^{3}$ Department of Physical and Life Sciences, Texas A\&M University-Corpus Christi, 6300 Ocean Drive, Corpus Christi, \\ Texas 78412, USA
}

\begin{abstract}
Bacterial mats, which are comprised of spatially distinct, pigmented and non-pigmented filamentous Beggiatoa, are abundant at hydrocarbon seeps on the continental slope of the northern Gulf of Mexico. Samples of both filament types were collected, using the submarine 'Johnson Sea Link', from seeps at water depths of $\sim 550 \mathrm{~m}$. The water-soluble pigment of colored strains was internal to the cells and had an absorbance peak of approximately $390 \mathrm{~nm}$. Sulfur granules in both pigmented and non-pigmented cells indicated that these Beggiatoa had the capability of oxidizing $\mathrm{H}_{2} \mathrm{~S}$. Non-pigmented filaments were capable of significant $\mathrm{CO}_{2}$ fixation based on incorporation of $\mathrm{CO}_{2}$ by whole, live cells and ribulose-1,5-bisphosphate carboxylase/oxygenase (RuBisCO) assays using cell-free extracts. RuBisCO activities for extracts from non-pigmented cells ranged from 9.92 to $135.35 \mathrm{nmol} \mathrm{CO}_{2}$ fixed mg protein ${ }^{-1} \mathrm{~min}^{-1}$. Activities varied significantly with temperature and $\mathrm{pH}$. This ability to use $\mathrm{CO}_{2}$ as the primary carbon source, along with the ability to oxidize $\mathrm{H}_{2} \mathrm{~S}$ for energy, suggests that these non-pigmented filaments were chemoautotrophic. Pigmented filaments, in contrast, had little $\mathrm{CO}_{2}$ incorporation ability. RuBisCO activities from pigmented mats ranged from 0.17 to $0.92 \mathrm{nmol} \mathrm{CO}_{2}$ fixed $\mathrm{mg}$ protein ${ }^{-1} \mathrm{~min}^{-1}$. These results suggest that geochemical processes at hydrocarbon seeps create an environment capable of supporting separate chemoautotrophic and heterotrophic (presumably organo-heterotrophic) Beggiatoa populations.
\end{abstract}

KEY WORDS: Bacterial mat · Autotrophy · Heterotrophy $\cdot$ Chemosynthetic community $\cdot$ Digital camera array

\section{Resale or republication not permitted without written consent of the publisher}

\section{INTRODUCTION}

Abundant bacterial mats, which consist of gliding, filamentous, sulfide-oxidizing Beggiatoa, are prevalent at hydrocarbon seep sites in the Gulf of Mexico (Larkin et al. 1994). A distinctive characteristic of Beggiatoa filaments at hydrocarbon seeps is their large size. Wirsen et al. (1992) found 2 size-classes consisting of 30 to $50 \mu \mathrm{m}$ and 85 to $108 \mu \mathrm{m}$ wide filaments, while Sassen et al. (1993) reported filaments as wide as $200 \mu \mathrm{m}$. These widths greatly exceed those of B. gigantea, which had been the largest known species having filament widths greater than $25 \mu \mathrm{m}$. This size range is comparable to that at the Guaymas Basin hydrothermal vents, where Beggiatoa as wide as $122 \mu \mathrm{m}$ have been collected (Nelson et al. 1989a). Beggiatoa mats in Gulf of Mexico seeps include non-pigmented (white) and pigmented (yellow to orange) colonies, which are spatially distinct as a general rule (MacDonald et al. 1989, Sassen et al. 1994, Larkin \& Henk 1996, Sen Gupta et al. 1997). The mats occur on sedimentary settings near faults and fractures, covering shallow gas-hydrate deposits, and peripheral to clusters of chemoautotrophic host organisms such as vestimentiferan tube worms Lamellibrachia sp. and seep mussels Bathymodiolus childressi (MacDonald et al. 1989, 1994, Fisher 1990, Gustafson et al. 1998). The orange pigmentation of some of the mats is not typical of the cytochromederived pink color that is commonly seen (Strohl \& Schmidt 1984), but its exact origin is still unclear. Mats of pigmented Beggiatoa have also been reported from cold seeps in Monterey Canyon (Barry et al. 1996) and 
from sediments adjacent to hydrothermal vents on Endeavour Ridge (Hedrick et al. 1992). The Beggiatoa at Gulf of Mexico seeps is unusual because one often observes distinct zonation of pigmented and nonpigmented mats over scales of a few $\mathrm{cm}$.

Sediment beneath Beggiatoa mats at hydrocarbon seeps contains high concentrations of hydrocarbon gases, $\mathrm{C}_{1}$ to $\mathrm{C}_{5}$, and oil that has undergone at least partial bacterial oxidation (Kennicutt \& Sassen 1995, Sassen et al. 1998). Sassen et al. (1994) reported substantially higher concentrations of hydrocarbons in sediments covered with pigmented mats than in those beneath adjacent non-pigmented mats. However, the gradients they observed were hundreds of parts per million over lateral and vertical scales of a few $\mathrm{cm}$. So, it is not clear whether the different pigmentation styles are associated with distinct geochemical environments or with transient pockets and veins of oil and gas in an extremely high-flux setting. The bacterial oxidation of this abundant organic carbon has an important impact on the seep environment. Bacterial oxidation of hydrocarbons causes depletion in the supply of $\mathrm{O}_{2}$ in the sediment and leads to the bacterial reduction of sulfate and production of $\mathrm{H}_{2} \mathrm{~S}$ (Aharon \& $\mathrm{Fu}$ 2000). The sediment at hydrocarbon seeps therefore contains an ample supply of both $\mathrm{CO}_{2}$ and $\mathrm{H}_{2} \mathrm{~S}$ in addition to organic compounds in the form of the hydrocarbons and bacterial metabolites derived from heterotrophic consumption of hydrocarbons. Such conditions would support microbial heterotrophy as well as autotrophy. Nelson et al. (1986) demonstrated chemoautotrophic growth by Beggiatoa in oxygensulfide micro-gradients. The characterization of hydrothermal vent Beggiatoa by Nelson, et al. (1989b) included measurements of ribulose-1,5-bisphosphate carboxylase/oxygenase (RuBisCO) activity and $\mathrm{CO}_{2}$ fixation. RuBisCO activities in filaments in the 24 to $32 \mu \mathrm{m}$ and 116 to $122 \mu \mathrm{m}$ width-classes were found to be at levels near those of known chemoautotrophs. Carbon isotope analysis reveals seep Beggiatoa biomass to have a light $\delta^{13} \mathrm{C}$ value of $-27.9 \%$ PDB (Sassen et al. 1993). This is compatible with typical values seen for chemoautotrophic carbon and lends credence to the idea that seep Beggiatoa use $\mathrm{CO}_{2}$ generated by the bacterial oxidation of hydrocarbons as their carbon source, and oxidize $\mathrm{H}_{2} \mathrm{~S}$ for energy.

Results reported by Wirsen et al. (1992) indicated significant rates of $\mathrm{CO}_{2}$ fixation for non-pigmented Beggiatoa from Gulf of Mexico seeps, whereas pigmented Beggiatoa had 'virtually no fixation activity.' This investigation was undertaken to examine evidence for multiple trophic modes in Beggiatoa from hydrocarbon seeps in the Gulf of Mexico and to determine whether distinct trophic modes are associated with filament size or pigmentation.

\section{MATERIALS AND METHODS}

Setting. Samples were collected from 2 principal hydrocarbon seeps on the northern continental slope of the Gulf of Mexico (Fig. 1). The deeper site, designated GC185 $\left(27^{\circ} 44^{\prime} \mathrm{N}, 91^{\circ} 30^{\prime} \mathrm{W}\right)$, consists of an elliptical mound, approximately $750 \mathrm{~m}$ long and $500 \mathrm{~m}$ wide and elevated approximately $40 \mathrm{~m}$ above the surrounding seafloor. Its crest is at a water depth of $570 \mathrm{~m}$. The mound is aligned along a low-angle fault that intersects the seafloor (Cook \& D'Onfro 1991) and provides a conduit for hydrocarbons that migrate to the seafloor from deeply buried reservoirs (Kennicutt et al. 1987). An abundant benthic fauna, including vestimentiferan tube worms, seep mussels, and associated heterotrophic animals, colonizes the fault axis along the crest of the mound (MacDonald et al. 1989). The second site, designated GC234 $\left(27^{\circ} 44^{\prime} \mathrm{N}, 91^{\circ} 33^{\prime} \mathrm{W}\right)$, is similarly colonized by seep fauna, but is situated in a half-graben at water depths of 525 to $550 \mathrm{~m}$ (Fig. 1). Thermogenic hydrocarbons, including gases (methane to pentane) and high molecular weight hydrocarbons (liquid oil), are prevalent in surface sediments of both sites (Sassen et al. 1994).

Bacterial mats were widespread at both sites. Typically, non-pigmented mats consist of reticulated strands that extend across the surface sediments in irregular arrays that can be $1 \mathrm{~m}$ or more in width. Pigmented mats generally appear denser and more compact. It is not uncommon to find distinct zones of pigmented mat surrounded by a fringe of non-pigmented filaments (Fig. 2A). Pigmented mats were often asso-

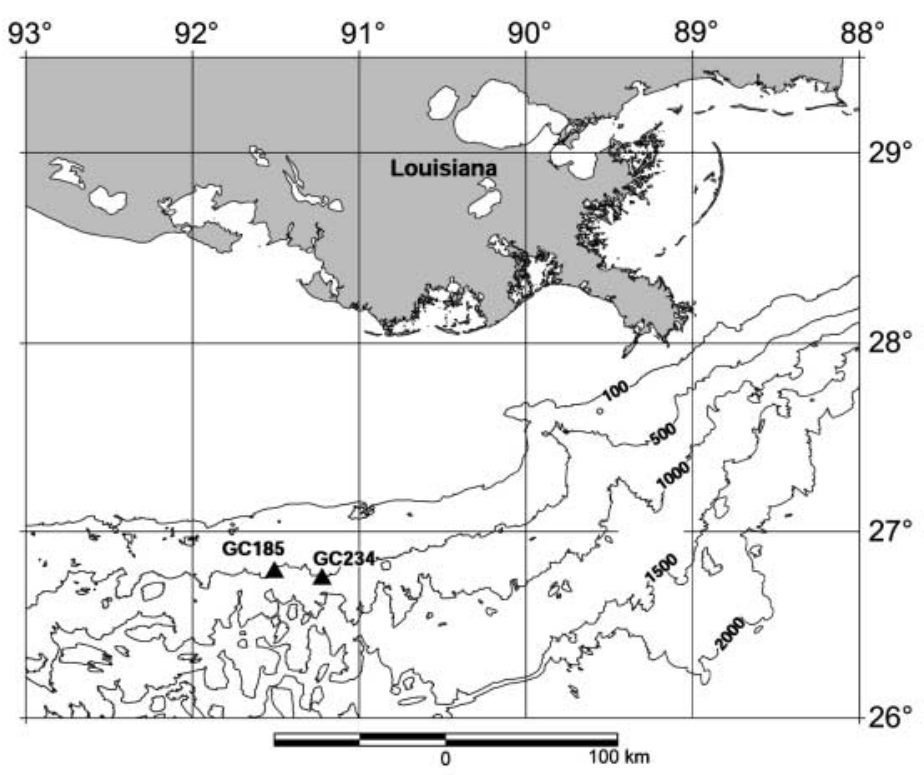

Fig. 1. Study sites in northern Gulf of Mexico ( $\mathbf{\Delta})$; see 'Materials and methods; Setting' for descriptions of sites. Depth contours in $\mathrm{m}$ 

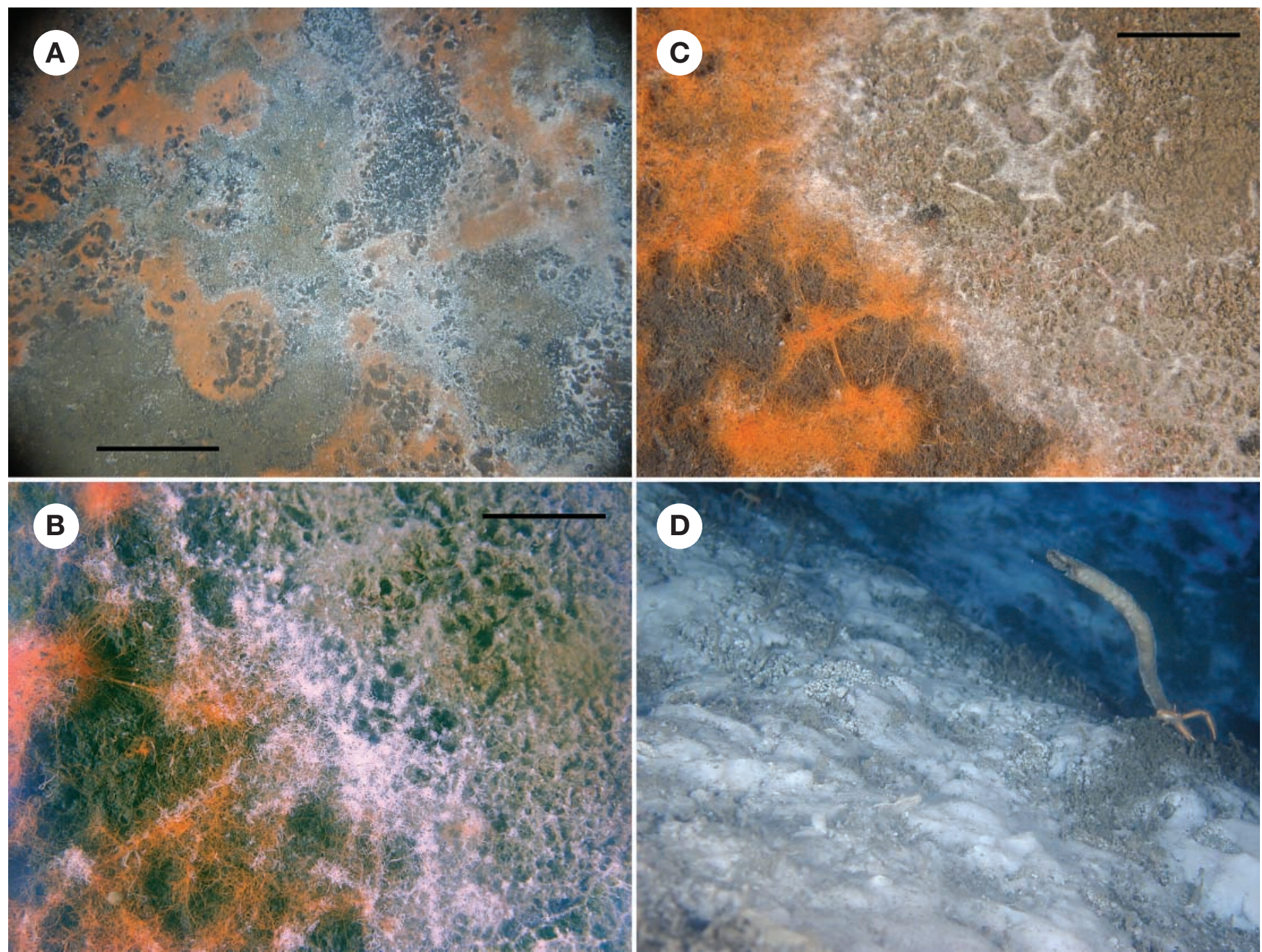

Fig. 2. Beggiatoa. Bacterial mats at GC234 study site, northern Gulf of Mexico. (A) Mix of pigmented and non-pigmented mats. Scale bar 10 cm. (B) Gradient between pigmented and non-pigmented mats. Scale bar $\sim 2 \mathrm{~cm}$. (C) Detail of gradient between pigmented and non-pigmented mats. Scale bar $\sim 1 \mathrm{~cm}$. (D) Detail of amorphous flocculent layer on sediments disturbed by sampling operations. The layer formed in a matter of days following disturbance and covered a total area $>15 \mathrm{~m}^{2}$

ciated with shallow or outcropping deposits of gas hydrate (MacDonald et al. 1994, Sassen et al. 1998).

Field methods. Collections of Beggiatoa were made using the submarine 'Johnson Sea Link'. High-resolution photographs of mats were taken with a newly designed digital camera array mounted on the submersible arm. The camera, a Nikon Coolpix $990^{\circledR}$, was modified to fit in a titanium alloy housing with a flat optical port. A pair of $250 \mathrm{~W}$ quartz lamps co-mounted with the housing provided light. Additional illumination for extreme close-ups was supplied by a 36-element LED array built into the lens adaptor. A continuous video signal to the observer in the submersible provided a preview image for frame and focus deter- mination. Camera function was controlled from the submarine by entering commands on a hand-held computer. The visual distinction between pigmented and non-pigmented mats is generally evident and, where the 2 types co-occur, the gradation from pigmented to non-pigmented filaments occurs over distances of $<1 \mathrm{~cm}$ (Fig. 2A-C). It was therefore possible to target collections of Beggiatoa mats based on their in-situ appearance. However, white, flocculent layers of amorphous sulfur, which contained few filaments, were sometimes confused with Beggiatoa mats (Fig. 2D). Beggiatoa mats were most successfully collected by gently suctioning them off surface sediment, through a hose $10 \mathrm{~cm}$ in diameter, and into Plexiglas 
containers lined with $50 \mu \mathrm{m}$ nylon mesh. Non-pigmented mats were collected from Sites GC234 and GC185, and pigmented mats were collected from GC185.

Upon return to the ship, the Plexiglas containers into which mat material was suctioned were immediately placed in the cold room. Beggiatoa filaments were then pipetted off the mesh linings and into cryovials. These were then centrifuged in the cold room to obtain moist pellets, which were frozen in liquid nitrogen until later use in protein and enzyme assays. Bacterial filaments were also placed in $50 \mathrm{ml}$ Falcon tubes and preserved in $2 \%$ glutaraldehyde for microscopy, including size range and morphology determination. Live filaments were set aside for use in shipboard $\mathrm{CO}_{2}$ incorporation experiments.

Microbiology methods. Bacterial filaments were identified as Beggiatoa based on morphology and size. The Beggiatoa width and morphology was determined from preserved and frozen material in which filaments were intact and undamaged. Filaments were wet mounted and viewed using an Olympus BH-2 microscope. One hundred filaments per slide were measured to determine width-frequency in the samples. Bright field photomicrographs were taken using the Olympus PM-10ADS automatic $35 \mathrm{~mm}$ camera system attached to the microscope.

Rates of carbon dioxide fixation were determined using fresh, live material. Immediately after collection, live filaments were pipetted into a $15 \mathrm{ml}$ vial containing $14 \mathrm{ml}$ of temperature equilibrated filtered seawater inoculated with $25 \mu \mathrm{l}$ of $0.25 \mu \mathrm{Ci} \mathrm{ml}{ }^{-1}$ $\mathrm{NaH}^{14} \mathrm{CO}_{3}, 10 \mathrm{mM}$ thiosulfate, and $100 \mu \mathrm{M}$ sulfide. The vial was then incubated in an $8^{\circ} \mathrm{C}$ water bath for $3 \mathrm{~h}$ with $2 \mathrm{ml}$ subsamples taken at 30,60 and $180 \mathrm{~min}$. The $2 \mathrm{ml}$ subsamples were filtered through $25 \mathrm{~mm}$ wide, $0.22 \mu \mathrm{m}$ Millipore filters using a multiple filtration system. The filters were then placed in scintillation vials and just covered with $0.5 \mathrm{~N} \mathrm{HCl}$. The capped and sealed vials were brought back to the lab where any remaining $\mathrm{HCl}$ was allowed to evaporate in the fume hood before the addition of scintillation cocktail. Uptake of ${ }^{14} \mathrm{C}$ was then counted with a liquid scintillation counter and converted to $\mathrm{nmol} \mathrm{CO}_{2}$ fixed mg dry weight (DW-1 $\mathrm{min}^{-1}$ as described below, substituting $\mathrm{mg}$ DW for $\mathrm{mg}$ protein. In addition to the samples, a killed control (sample 3 to $4 \%$ glutaraldehyde by volume) and live samples lacking thiosulfate and sulfide were also analyzed (Nelson et al. 1989a). The dry weight of mat material contained within the $2 \mathrm{ml}$ subsamples was determined by filtration onto a $47 \mathrm{~mm}$ pre-weighed filter, air drying, and weighing. Rates of carbon dioxide fixation were not corrected for the total carbon dioxide of seawater because of the uncertainties in this calculation (see additional information in 'Discussion' section).
RuBisCO activities were measured using cryo-frozen material. Upon return to the lab, bacteria samples stored in liquid nitrogen were transferred to a $-80^{\circ} \mathrm{C}$ freezer. Prior to use, each vial containing a Beggiatoa sample was placed in a refrigerator at $4^{\circ} \mathrm{C}$ to allow the filaments to thaw slowly. Enzyme assays were conducted by the method of Beudeker et al. (1980), with minor modifications for Beggiatoa. A subsample was pipetted into a $1.5 \mathrm{ml}$ Eppendorf vial containing assay buffer solution (100 mM Tris buffer, $5 \mathrm{mM}$ dithiothreitol, $20 \mathrm{mM} \mathrm{MgCl}_{2}, 5 \mathrm{mM} \mathrm{NaHCO}_{3}$ adjusted to a $\mathrm{pH}$ of 8.2 at $20^{\circ} \mathrm{C}$ ) in an ice bath. The cells were then sonicated for $5 \times 20 \mathrm{~s}$ periods using a sonicator (Branson 25) fitted with a microtip. The resulting cell-free extract was centrifuged for $30 \mathrm{~min}$ in a microfuge at $12500 \times \mathrm{g}$ at $4{ }^{\circ} \mathrm{C}$ to remove debris. The supernatant $(270 \mu \mathrm{l})$ was pipetted into a $1.5 \mathrm{ml}$ Eppendorf vial and activated by incubation for $10 \mathrm{~min}$ at room temperature. Following activation, $20 \mu \mathrm{l}$ of a $2: 1$ mixture of $1 \mathrm{mM}$ 'cold' sodium carbonate and $\mathrm{NaH}^{14} \mathrm{CO}_{3}\left(57.3 \mathrm{mCi} \mathrm{mmol}{ }^{-1}\right)$ solution was added, followed $15 \mathrm{~s}$ later by $20 \mu \mathrm{l}$ of $0.01 \mathrm{M}$ ribulose-1,5-bisphosphate (RuBP), which began the reaction. The vials containing the samples were placed in a $15^{\circ} \mathrm{C}$ water bath to allow the reaction to proceed at this temperature. Subsamples consisting of $75 \mu$ were taken at 1, 5, 20, and 60 min and placed in separate scintillation vials containing $400 \mu \mathrm{l}$ of $50 \% \mathrm{HCl}$ and allowed to sit overnight in the fume hood. After the $\mathrm{HCl}$ had driven off any unfixed ${ }^{14} \mathrm{CO}_{2}$, incorporation of ${ }^{14} \mathrm{C}$ was determined in a liquid scintillation counter. Results were then expressed as $\mathrm{nmol} \mathrm{CO}_{2}$ fixed $\mathrm{mg}$ protein ${ }^{-1} \mathrm{~min}^{-1}$.

In addition to the samples, 3 controls were prepared and assayed as described above. A killed control contained cell free extract to which a final concentration of $5 \%$ glutaraldehyde had been added. The killed control was allowed to sit for $10 \mathrm{~min}$ prior to addition of $\mathrm{NaH}^{14} \mathrm{CO}_{3}$. A live control contained active enzyme but lacked RuBP, and the final control contained only assay buffer.

To find the optimum temperature of enzyme activity in the cell-free extract, the above assay was also run at $4,8,32,45,55$, and $60^{\circ} \mathrm{C}$. Samples adjusted to a $\mathrm{pH}$ of 7.0 at $8,15,32,39$, and $45^{\circ} \mathrm{C}$ were also assayed to account for the change of $\mathrm{pH}$ in Tris buffer with changing temperature. The optimum $\mathrm{pH}$ was determined by running the assay at $\mathrm{pH}$ values of $7.0,8.2$, and 9.0. The bicarbonate and RuBP dependence of RuBisCO activity were investigated by running the assay at $\mathrm{NaHCO}_{3}$ concentrations ranging from 0.05 to $19.3 \mathrm{mM}$ and RuBP concentrations from 0 to $1.0 \mathrm{M}$ in separate experiments.

The amount of protein in each sample was determined using the Pierce Bicinchoninic acid (BCA) protein assay according to the instructions included with 
the assay kit. Since the samples contained the interfering substance DTT (dithio-threitol), an assay procedure using deoxycholate and TCA (trichloroacetic acid) was used to eliminate interfering substances. Following this treatment, the BCA Working Reagent $(1.0 \mathrm{ml})$ was added to the sample which was then vortexed. The samples were then incubated for $30 \mathrm{~min}$ at $37^{\circ} \mathrm{C}$ and allowed to cool to room temperature. The absorbance of each sample was then measured at $562 \mathrm{~nm}$ in a spectrophotometer. The concentration of protein in each sample was determined by plotting the absorbance of each sample on a standard curve with protein concentrations ranging from 25 to $400 \mu \mathrm{g} \mathrm{ml}^{-1}$.

\section{RESULTS}

\section{Beggiatoa filament width and morphology}

The pigmentation differences were generally very distinct upon close examination of Beggiatoa mats (Fig. 2). Preserved non-pigmented Beggiatoa material sampled from GC185 contained filaments ranging in diameter from 20 to $95 \mu \mathrm{m}$ (Fig. 3). The widths observed comprised a continuum of sizes rather than distinct groups. The narrowest filaments $(<25 \mu \mathrm{m}$ wide) and the widest filaments (>85 $\mu \mathrm{m}$ wide) represented a small fraction while more than half the filaments were 25 to $45 \mu \mathrm{m}$ wide. All of the filaments, regardless of size, were composed of cells that contained an abundance of sulfur granules and exhibited the 'hollow' appearance typical of larger Beggiatoa filaments (Larkin \& Strohl 1983). Two types of filament were observed: those that were smooth and straight in form and those that appeared knobby and uneven. Complete filaments displayed rounded ends, which are characteristic of this genus. There was no evidence of bundles of filaments contained in a common sheath

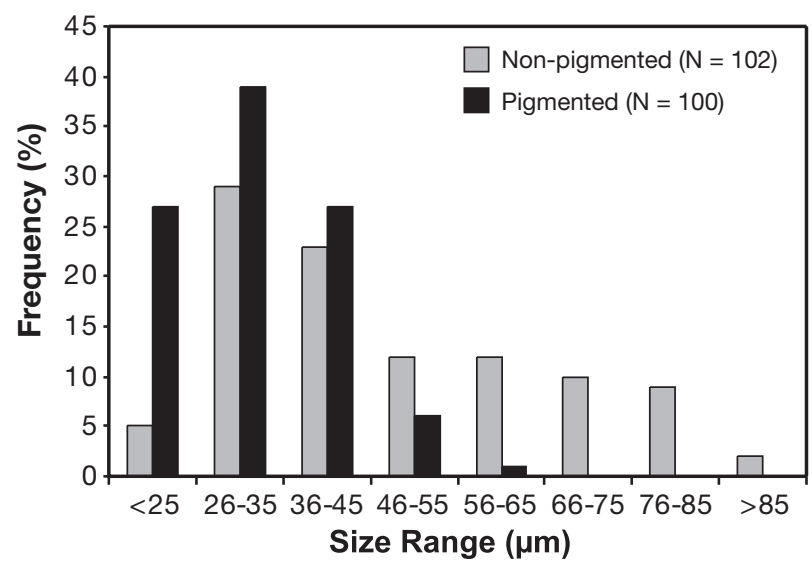

Fig. 3. Beggiatoa. Size-frequency distribution of pigmented and non-pigmented filaments from Site GC185 or of filaments with tapered ends, as often found in the closely related genera Thioploca and Thiothrix (Larkin \& Strohl 1983, Jorgensen \& Gallardo 1999).

Pigmented Beggiatoa filaments sampled from GC185 displayed a continuum of widths ranging from 20 to $65 \mu \mathrm{m}$ (Fig. 3). While the 25 to $45 \mu \mathrm{m}$ group was again the most abundant, filaments $<25 \mu \mathrm{m}$ wide represented a much greater proportion of the diameters observed than in the non-pigmented sample from the same site. The largest filaments, $>55 \mu \mathrm{m}$ wide, were the least abundant. The pigmented filaments exhibited characteristic rounded ends and seemed to be mostly knobby and uneven in form. It is possible that freezing affected the morphology of some of the filaments that had been frozen. Individual cells appeared hollow and contained numerous sulfur granules. The orange pigmentation of these filaments appeared to be internal and of varying degrees of intensity among the filaments and within individual filaments. This pigmentation, which is unlike the pink cytochrome tint, is soluble in both distilled water and assay buffer, and has an absorbance peak at a wavelength of approximately $390 \mathrm{~nm}$.

Non-pigmented Beggiatoa filaments from GC234 were a uniform population 16 to $19 \mu \mathrm{m}$ wide with a smooth, straight appearance (not shown). These filaments also exhibited characteristic rounded ends and were composed of apparently hollow cells with abundant sulfur inclusions. The filaments appeared to be tinted pink when clustered together, presumably as a result of cytochromes within the cells.

\section{Carbon dioxide incorporation}

Shipboard $\mathrm{CO}_{2}$ incorporation experiments showed non-pigmented Beggiatoa filaments from Site GC234 to be capable of appreciable levels of $\mathrm{CO}_{2}$ uptake (Fig. 4A). The non-pigmented filaments incorporated $\mathrm{CO}_{2}$ at a rate of $0.017 \mathrm{nmol} \mathrm{CO} \mathrm{mg} \mathrm{DW}^{-1} \mathrm{~min}^{-1}$ at $8^{\circ} \mathrm{C}$, the ambient water temperature at the seep sites. This rate increased to $0.033 \mathrm{nmol} \mathrm{CO} \mathrm{mg} \mathrm{DW}^{-1} \mathrm{~min}^{-1}$ when samples were supplemented with $10 \mathrm{mM}$ thiosulfate and $100 \mu \mathrm{m}$ sulfide. A killed control (3 to $4 \%$ glutaraldehyde by volume) also supplemented with $10 \mathrm{mM}$ thiosulfate and $100 \mu \mathrm{m}$ sulfide showed no $\mathrm{CO}_{2}$ uptake.

Pigmented Beggiatoa filaments from GC234 showed little $\mathrm{CO}_{2}$ incorporation ability (Fig. 4B). The rate of uptake for unsupplemented filaments was $0.004 \mathrm{nmol}$ $\mathrm{CO}_{2} \mathrm{mg} \mathrm{DW}{ }^{-1} \mathrm{~min}^{-1}$ at $8^{\circ} \mathrm{C}$. This rate was unchanged at $0.003 \mathrm{nmol} \mathrm{CO}_{2} \mathrm{mg} \mathrm{DW}^{-1} \mathrm{~min}^{-1}$ for cells supplemented with $10 \mathrm{mM}$ thiosulfate and $100 \mu \mathrm{m}$ sulfide. The incorporation rate for a thiosulfate- plus sulfidesupplemented killed control was negligible over a 150 min time-course (0.002 $\mathrm{nmol} \mathrm{CO}_{2} \mathrm{mg} \mathrm{DW}^{-1} \mathrm{~min}^{-1}$ ). 


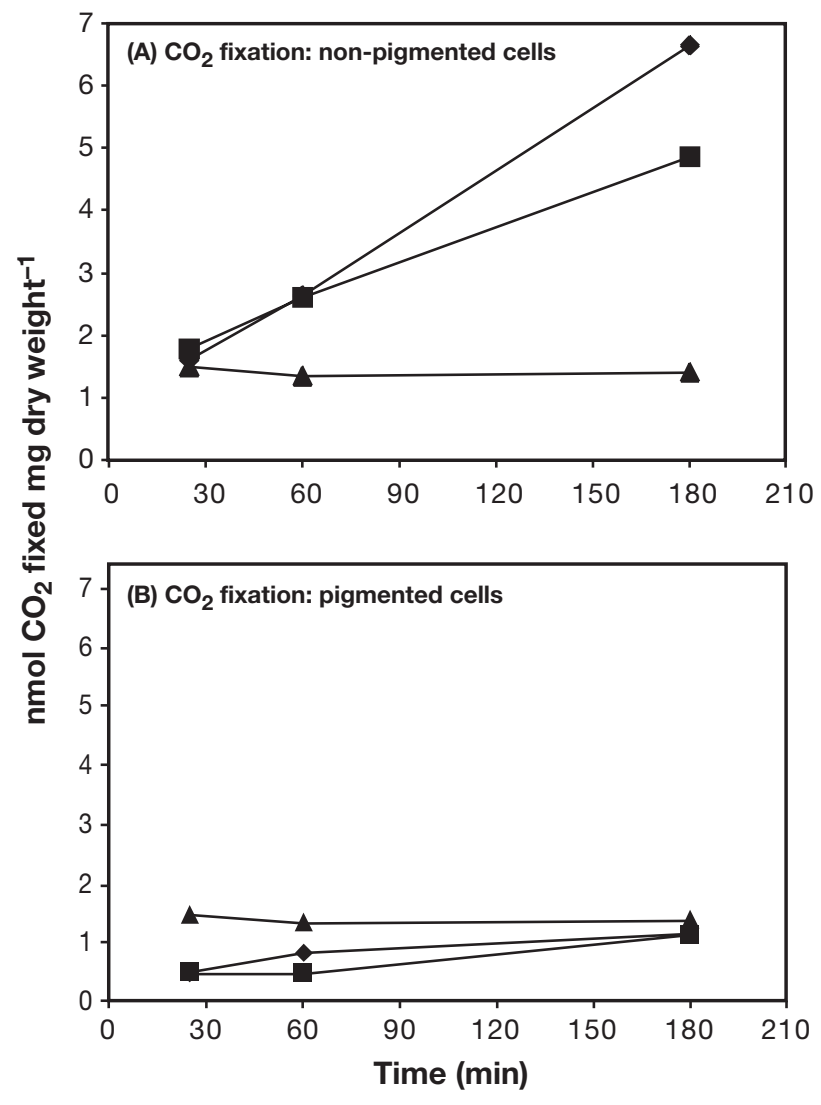

Fig. 4. Beggiatoa. Time course determinations of chemosynthetic $\mathrm{CO}_{2}$ fixation for (A) non-pigmented and (B) pigmented cells. Live and supplemented with $10 \mathrm{mM}$ thiosulfate and $100 \mu \mathrm{m}$ sulfide $(\bullet)$, live unsupplemented (ם), killed control supplemented with $10 \mathrm{mM}$ thiosulfate and $100 \mu \mathrm{m}$ sulfide (\)

\section{RuBisCO activity}

RuBisCO assays, summarized in Table 1, were initially run at $15^{\circ} \mathrm{C}$ and a pH of 8.5 with $0.01 \mathrm{M} \mathrm{RuBP}$ added to each sample. Under these conditions, cellfree extract derived from non-pigmented Beggiatoa filaments from site GC 234 showed significant RuBisCO activity ranging from 7.78 to $13.60 \mathrm{nmol} \mathrm{CO}_{2}$ mg protein ${ }^{-1} \mathrm{~min}^{-1}$, with an average of $9.65 \mathrm{nmol} \mathrm{CO}_{2}$ $\mathrm{mg}$ protein ${ }^{-1} \mathrm{~min}^{-1}$. Killed controls (5\% glutaraldehyde by volume) for each assay showed no activity. Controls consisting of only buffer solution with no extract added showed virtually no RuBisCO activity (an average of $0.02 \mathrm{nmol} \mathrm{CO}_{2} \mathrm{mg}$ protein ${ }^{-1} \mathrm{~min}^{-1}$ ). Controls that lacked supplemental RuBP also showed extremely low activity levels (an average of $0.09 \mathrm{nmol} \mathrm{CO}_{2} \mathrm{mg}$ protein $^{-1} \mathrm{~min}^{-1}$ ). Because all these control values were $<2 \%$ of the average measured activity, they were not subtracted from the activity.

In contrast, RuBisCO activities measured under identical conditions in cell-free extract derived from pigmented filaments from GC185 yielded RuBisCO activities that were $<5 \%$ of activities recorded for nonpigmented Beggiatoa. Rates for the pigmented extract ranged from 0.18 to $0.57 \mathrm{nmol} \mathrm{CO}_{2} \mathrm{mg}_{\text {protein }}{ }^{-1} \mathrm{~min}^{-1}$ with an average of $0.41 \mathrm{nmol} \mathrm{CO}_{2} \mathrm{mg}$ protein ${ }^{-1} \mathrm{~min}^{-1}$ (Table 1). As with the controls from non-pigmented filaments, killed controls and those lacking extract or RuBP showed no RuBisCO activity. However, spinach extract run as a positive control had high RuBisCO activity, ranging from 636.62 to $1618.13 \mathrm{nmol} \mathrm{CO} \mathrm{CO}_{2} \mathrm{mg}$ protein $^{-1} \mathrm{~min}^{-1}$.

Additional RuBisCO activities, measured over a wide range of temperatures, $\mathrm{pH}$ values, and RuBP concentrations in both non-pigmented and pigmented filaments, are summarized in Table 1. Mean RuBisCO activities, averaged over all these experiments, were nearly 100 times higher for non-pigmented as compared with pigmented filaments.

RuBisCO activity from non-pigmented filaments was also evaluated over a range of temperatures, $\mathrm{pH}$ values, RuBP concentrations, and bicarbonate concentrations. Activity increased with incubation temperature from 4 to $45^{\circ} \mathrm{C}$ to a maximum activity of $62.19 \mathrm{nmol}$ $\mathrm{CO}_{2}$ mg protein ${ }^{-1} \mathrm{~min}^{-1}$ (Fig. 5A). RuBisCO activity at $55^{\circ} \mathrm{C}$ dropped to ca. half of the $45^{\circ} \mathrm{C}$ rate, and was only $14 \%$ of the maximum rate at $60^{\circ} \mathrm{C}$. These rates, however, may also have been influenced by the decrease of $0.03 \mathrm{pH}$ units for every $1^{\circ} \mathrm{C}$ increase in temperature which occurs in Tris buffer. The actual $\mathrm{pH}$ at each temperature is shown in Fig. 5A, and the general pattern was similar to the $\mathrm{pH}$-corrected temperature plot shown in Fig. 5B. Samples adjusted to a pH of 7.0 at each temperature showed increasing RuBisCO activity

Table 1. Beggiatoa. RuBisCO activities (nmol $\mathrm{CO}_{2}$ fixed $\mathrm{mg}$ protein ${ }^{-1} \mathrm{~min}^{-1}$ ) for filaments of pigmented ( 6 assays) and nonpigmented (37 assays) varieties. Uniform assays were conducted at constant $\mathrm{pH}$ and temperature

\begin{tabular}{|lrcccrrr|}
\hline $\begin{array}{l}\text { Filament type } \\
\text { (assay subset) }\end{array}$ & $\mathrm{N}$ & $\begin{array}{c}\text { Temp. } \\
\left({ }^{\circ} \mathrm{C}\right)\end{array}$ & $\mathrm{pH}$ & $\mathrm{RuBP}(\mathrm{M})$ & $\begin{array}{c}\text { Mean } \\
\text { RuBisCO activity }\end{array}$ & $\begin{array}{c}\text { Median } \\
\text { RuBisCO activity }\end{array}$ & $\begin{array}{c}\text { Standard } \\
\text { deviation }\end{array}$ \\
\hline Non-pigmented (uniform) & 8 & 15 & 8.5 & 0.01 & 9.65 & 9.41 & 1.97 \\
Pigmented (uniform) & 3 & 15 & 8.5 & 0.01 & 0.41 & 0.47 & 0.20 \\
Non-pigmented (all assays) & 37 & $4-60$ & $7-9$ & $0.01-1.0$ & 45.56 & 0.54 & 0.52 \\
Pigmented (all assays) & 6 & $8-45$ & $7-8.5$ & $0.01-0.1$ & 0.33 \\
\hline
\end{tabular}




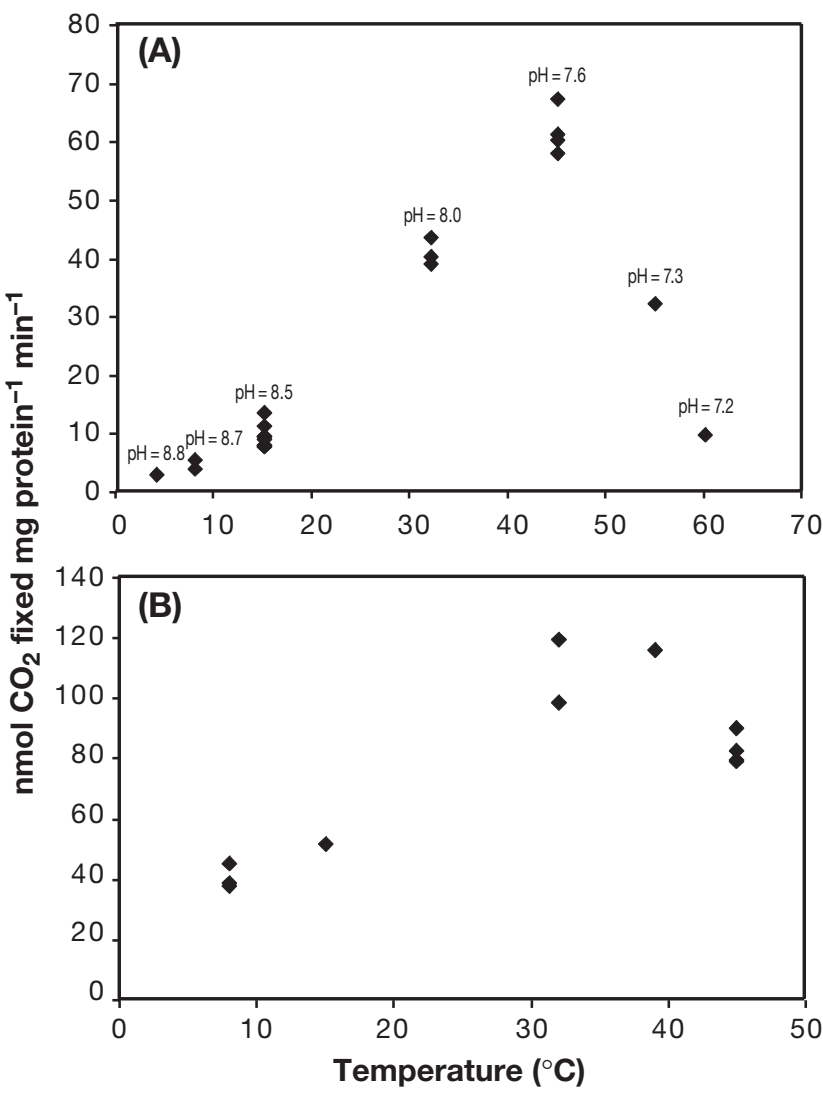

Fig. 5. (A) Ribulose-1,5-bisphosphate carboxylase/oxygenase (RuBisCO) activities versus assay temperature for cell-free extract, where (A) assay buffer varied with temperature (concentration of ribulose-1,5-bisphosphate $[\mathrm{RuBP}]=0.01$ $\mathrm{mol}^{-1}$ ) and (B) $\mathrm{pH}$ was adjusted to 7.0 for each temperature $\left(\mathrm{RuBP}=0.10 \mathrm{~mol} \mathrm{l}^{-1}\right)$

from incubation temperatures of 8 to $32^{\circ} \mathrm{C}$, where the average activity was $109.03 \mathrm{nmol} \mathrm{CO}_{2}$ mg protein ${ }^{-1}$ $\min ^{-1}$ (Fig. 5B). At $39^{\circ} \mathrm{C}$, activity increased slightly to $115.87 \mathrm{nmol} \mathrm{CO}_{2} \mathrm{mg}$ protein ${ }^{-1} \mathrm{~min}^{-1}$. By $45^{\circ} \mathrm{C}$, the RuBisCO activity had dropped to $73 \%$ of the $39^{\circ} \mathrm{C}$ activity level.

In limited experiments, a pH of 7 was optimal for RuBisCO activity in non-pigmented extract, with a maximum activity of $86.43 \mathrm{nmol} \mathrm{CO}_{2} \mathrm{mg}$ protein $^{-1}$ $\min ^{-1}$. Activities at $\mathrm{pH}$ values of 8.2 and 9.0, respectively, were only 29 and $13 \%$ of the maximal RuBisCO activity. Lower $\mathrm{pH}$ values were not examined. Measurement of $\mathrm{pH}$ in sediments associated with Beggiatoa mats at the 2 sampling sites has detected a range of $\mathrm{pH}$ values between 7.4 and 8.1 (MacDonald et al. 2002).

Maximal RuBisCO activity was obtained with RuBP concentrations of $0.1 \mathrm{M}$ or higher, though 0.01 M RuBP yielded more than $80 \%$ of maximal activity. RuBisCO activity at $\mathrm{NaHCO}_{3}$ concentrations from 0.05 to $19.3 \mathrm{mM}$ increased slowly below $2 \mathrm{mM}$ and more rapidly at higher concentrations. RuBisCO activity did not saturate at the highest bicarbonate concentration used (19.3 mM), so kinetic parameters were not calculated.

\section{DISCUSSION}

The range in filament size and morphology for the Beggiatoa populations examined in this study was consistent with previous descriptions of Beggiatoa from the Gulf of Mexico (Sassen et al. 1993, Larkin et al. 1994). These attributes appear to be characteristic of Beggiatoa populations at mid-slope hydrocarbon seeps in this region. The filament sizes were within the range (20 to $150 \mu \mathrm{m}$ ) reported for chemoautotrophic populations of Beggiatoa at hydrothermal vents (Nelson et al. 1986), Guaymas Basin hot vents (Nelson et al. 1989a), and cold seeps (McHatton et al. 1996). However, whereas Nelson et al. (1989a) reported 3 distinct width-classes, filament widths of pigmented and nonpigments filaments in our samples were overlapping and appeared to be normally distributed over the full range. Filament size is an important characteristic in Beggiatoa cells because it results from the presence of a large vacuole, which is used to accumulate nitrate from seawater overlying anoxic sediments (McHatton et al. 1996). The vacuole allows Beggiatoa to extend its habitat over a greater sediment depth near the sediment-water interface. In our cores, Beggiatoa were observed to withdraw $10 \mathrm{~cm}$ or deeper into the sediment, probably in response to the collection insult; subsequently the filaments would migrate back to surface sediments. Wirsen et al. (1992) reported high populations of free-living microbes in sediment beneath mats $\left(2.96 \times 10^{9} \mathrm{ml}^{-1}\right)$ and in oily sediments $\left(3.96 \times 10^{9}\right.$ $\mathrm{ml}^{-1}$ ), indicative of rich organic sediments.

Wirsen et al. (1992) reported $\mathrm{CO}_{2}$ uptake rates averaging $57.5 \mathrm{nmol} \mathrm{CO}_{2}$ fixed $\mathrm{mg} \mathrm{DW}^{-1} \mathrm{~h}^{-1}$ in nonpigmented Beggiatoa from seeps in the Gulf of Mexico. The assays were conducted in artificial seawater of known bicarbonate concentration at $8^{\circ} \mathrm{C}$, approximately the in situ temperature of the Beggiatoa. Corresponding assays of orange mat material produced virtually no fixation activity. Without a correction for the total $\mathrm{CO}_{2}$ in seawater (see below), the rate of $\mathrm{CO}_{2}$ incorporation in our assays (also at $8^{\circ} \mathrm{C}$, Fig. 4) was considerably lower than Wirsen et al. (1992) reported for non-pigmented samples. However, we also found a clear difference in the $\mathrm{CO}_{2}$ uptake rates between the pigmented and non-pigmented mats, with higher uptake by the non-pigmented mats. In addition, as in Wirsen et al. (1992), the non-pigmented mats responded to supplementation with sulfide and thiosulfate; the pigmented mats did not. 
The total dissolved inorganic carbon concentration (DIC) in seawater is about $2 \mathrm{mM}$, though concentrations in seep areas can be another $0.5 \mathrm{mM}$ higher (Aharon et al. 1992). At seawater $\mathrm{pH}$, however, only a small fraction of the DIC is $\mathrm{CO}_{2}$ (Aharon et al. 1992). Using the total $2 \mathrm{mM}$ DIC concentration to correct our $\mathrm{CO}_{2}$ uptake measurements, we calculated high uptake rates for non-pigmented Beggiatoa of up to $721 \mathrm{nmol}$ $\mathrm{CO}_{2}$ fixed $\mathrm{mg} \mathrm{DW} \mathrm{DW}^{-1} \mathrm{~h}^{-1}$. This rate is more than 10 times that reported by Wirsen et al. (1992) for samples incubated in artificial seawater, though apparently still less than a lab study with freshwater Beggiatoa (Grabovich et al. 2001). Regardless of how the $\mathrm{CO}_{2}$ fixation rate is calculated, the pattern of activity is consistent with the measured RuBisCO activities.

We measured RuBisCO activities in non-pigmented Beggiatoa that indicate chemoautotrophic nutrition and are consistent with values reported for chemosynthetic Beggiatoa from other environments (Nelson et al. 1989a). The RuBisCO activities for non-pigmented Beggiatoa from Gulf of Mexico seeps reported here were much higher than those found by other workers (Wirsen et al. 1992). Positive RuBisCO assays were obtained only when the samples were centrifuged and the pellets frozen under liquid nitrogen. These steps may be crucial for detection of enzyme activities in these populations.

To obtain usable samples in the field, it was also crucial to distinguish Beggiatoa mats from white flocculent layers that contained few if any Beggiatoa. Dense flocculent layers were developed in a matter of days in areas where the submarine's sampling activities had disturbed the bottom sediment (Fig. 2D). Inspection of fresh collections of floc under a compound microscope revealed no filaments. Laboratory cultures of vibrioid organisms were induced to form similar accumulations of amorphous sulfur by flowing a steady stream of $\mathrm{H}_{2} \mathrm{~S}$ into organic-rich soils (Taylor \& Wirsen 1997). It is probable that disturbance of the bottom enhances the diffusion of $\mathrm{H}_{2} \mathrm{~S}$ from deeper anoxic layers. The rapid and opportunistic response of a diverse microbial community to transient gradients and venting processes appears to be a hallmark of the organically enriched, but highly heterogeneous seep environment.

These 2 pigmentation types of Beggiatoa from the Gulf of Mexico seeps are distinct and reproducible. Pigmented filaments often appeared knobby and less robust than non-pigmented filaments. Although this may have been an artifact of preservation, the effect was different between the filament types and is consistent with observations reported by Wirsen et al. (1992). Abrupt transitions between the 2 varieties strongly suggest competitive exclusion.

Our results support the interpretation that the pigmentation types have trophic significance. There are
3 possible trophic modes for these bacteria. First, the non-pigmented Beggiatoa in these settings may be autotrophic organisms that utilize $\mathrm{CO}_{2}$ as a carbon source and oxidize $\mathrm{H}_{2} \mathrm{~S}$ for energy. Second, nonpigmented seep Beggiatoa may be facultatively mixotrophic in nature, using hydrocarbons or another source of organic material for their carbon supply and $\mathrm{H}_{2} \mathrm{~S}$ as an energy source. Mixotrophic potential, as defined by Otte et al. (1999), is the use of sulfide or sulfur as an energy source for $\mathrm{CO}_{2}$ fixation with incorporation of acetate as an additional organic carbon source. Finally, pigmented and non-pigmented Beggiatoa may be heterotrophic and not need $\mathrm{H}_{2} \mathrm{~S}$ for energy, but are able to fulfill both their carbon and energy requirements through oxidation of the seeping hydrocarbons or possibly other organic compounds. The lack of RuBisCO activity and carbon fixation in the pigmented Beggiatoa suggests that these cells are probably heterotrophic. Although there has been speculation, based on structural evidence, that pigmented Beggiatoa may be capable of methanotrophy (Larkin \& Henk 1996), we believe that heterotrophy induced by locally high concentrations of hydrocarbons is a more plausible explanation (MacDonald et al. 2002). However, both pigmented and non-pigmented Beggiatoa were found in sediments with high $\mathrm{H}_{2} \mathrm{~S}$ concentrations and accumulated sulfur granules. This suggests that $\mathrm{H}_{2} \mathrm{~S}$ remains important for both varieties, even though pigmented Beggiatoa may not need it as an energy source.

Facultative mixotrophy might expand the niches available for colonization by non-pigmented Beggiatoa. Through their proposed activities of $\mathrm{CO}_{2}$ fixation, sulfide oxidation, and consumption of hydrocarbon breakdown products, these Beggiatoa would also have greater capacity to link and influence the carbon and sulfur cycles at hydrocarbon seep sites than would be the case if they were strictly chemoautotrophic. However, although it is readily possible to collect the 2 pigmentation types for analysis, sampling very easily disturbs micro-gradients in the sediments. Use of techniques such as microelectrodes deployed in situ is needed to improve understanding of the geochemical niches that support differently pigmented Beggiatoa in Gulf of Mexico hydrocarbon seeps.

Acknowledgements. We thank the crews of the Johnson Sea Link submarine and her support ship RV 'Edwin Link' for assistance in the field. Discussions with $\mathrm{H}$. Schulz and S. Joye contributed to our understanding of mat-forming processes at hydrocarbon seeps. Careful review of the manuscript by D.C. Nelson was very helpful. This work was supported by the Minerals Management Service Gulf of Mexico Regional OCS Office under contracts 30555 and 31813; NSF LExEn OCE0085549 (to IRM), and by the National Undersea Research Center, University of North Carolina at Wilmington. 


\section{LITERATURE CITED}

Aharon P, Fu BS (2000) Microbial sulfate reduction rates and sulfur and oxygen isotope fractionations at oil and gas seeps in deepwater Gulf of Mexico. Geochim Cosmochim Acta 64:233-246

Aharon P, Graber ER, Roberts, HH (1992) Dissolved carbon and $\delta^{13} \mathrm{C}$ anomalies in the water column caused by hydrocarbon seeps in the northwestern Gulf of Mexico slope. Geo-Mar Lett 12:33-40

Barry JP, Greene HG, Orange DL, Baxter CH and 5 others (1996) Biologic and geologic characteristics of cold seeps in Monterey bay, California. Deep-Sea Res 43:1739-1762

Beudeker RF, Cannon GC, Kuenen JG, Shively JM (1980) Relations between D-ribulose-1,5-bisphosphate carboxylase, carboxysomes and $\mathrm{CO}_{2}$ fixing capacity in the obligate chemolithotroph Thiobacillus neapolitanus grown under different limitations in the chemostat. Arch Microbiol 124:185-189

Cook D, D'Onfro P (1991) Jolliet Field thrust fault structure and stratigraphy Green Canyon Block 184, offshore Louisiana. Trans Gulf Coast Assoc Geol Soc 41:100-121

Fisher CR (1990) Chemoautotrophic and methanotrophic symbioses in marine invertebrates. Rev Aquat Sci 2: 399-436

Grabovich MY, Patritskaya VY, Muntyan MS, Dubinina GA (2001) Lithoautotrophic growth of the freshwater strain Beggiatoa D-402 and energy conservation in a homogenous culture under microoxic conditions. FEMS Microbiol Lett 204: 341-345

Gustafson RG, Turner RD, Lutz RA, Vrijenhoek RC (1998) A new genus and five new species of mussels (Bivalvia, Mytilidae) from deep-sea sulfide/hydrocarbon seeps in the Gulf of Mexico. Malacologia 40:63-112

Hedrick DB, Pledger RD, White DC, Baross JA (1992) In situ microbial ecology of hydrothermal vent sediments. FEMS Microbiol Ecol 101:1-10

Jorgensen, BB, Gallardo VA (1999) Thioploca spp.: filamentous sulfur bacteria with nitrate vacuoles. FEMS Microbiol Ecol 28:301-313

Kennicutt MC, Sassen R (1995) Geochemical alteration of hydrocarbons in seep systems. In: MacDonald I, Schroeder W, Brooks J (eds) Chemosynthetic Ecosystems Study Final Report (MMS 95-0023). US Dept. Interior, Minerals Management Service, Gulf of Mexico OCS Region, New Orleans, p 4.1-4.35

Kennicutt MC, Sericano J, Wade T, Alcazar F, Brooks JM (1987) High-molecular weight hydrocarbons in the Gulf of Mexico continental slope sediment. Deep-Sea Res 34: 403-424

Larkin JM, Henk MC (1996) Filamentous sulfide-oxidizing bacteria at hydrocarbon seeps of the Gulf of Mexico. Microsc Res Tech 33:23-31

Larkin JM, Strohl WR (1983) Beggiatoa, Thiothrix, and Thioploca. Annu Rev Microbiol 37:341-367

Larkin J, Aharon P, Henk MC (1994) Beggiatoa in microbial mats at hydrocarbon vents in the Gulf-of-Mexico and warm-mineral-springs, Florida. Geo-Mar Lett 14:97-103

MacDonald IR, Boland GS, Baker JS, Brooks JM, Kennicutt

Editorial responsibility: Gary King,

Walpole, Maine, USA
MC II, Bidigare RR (1989) Gulf of Mexico chemosynthetic communities II: spatial distribution of seep organisms and hydrocarbons at Bush Hill. Mar Biol 101:235-247

MacDonald IR, Guinasso NL Jr, Sassen R, Brooks JM, Lee L, Scott KT (1994) Gas hydrate that breaches the sea floor on the continental slope of the Gulf of Mexico. Geol 22: 699-702

MacDonald IR, Arvidson R, Carney RS, Fisher CF and 10 others (2002) Stability and change in Gulf of Mexico chemosynthetic communities: Final Report (Contract 1435-001-31813). US Dept. Interior, Minerals Management Service, Gulf of Mexico OCS Region, New Orleans

McHatton SC, Barry JP, Jannasch HW, Nelson DC (1996) High nitrate concentrations in autotrophic, vacuolate marine Beggiatoa. spp. Appl Environ Microbiol 62:954-958

Nelson DC, Revsbech NP, Jorgenson BB (1986) Microoxicanoxic niche of Beggiatoa spp.: microelectrode survey of marine and freshwater strains. Appl Environ Microbiol 52: 161-168

Nelson DC, Wirsen CO, Jannasch HW (1989a) Characterization of large autotrophic Beggiatoa spp. abundant at hydrothermal vents of the Guaymas Basin. Appl Environ Microbiol 55:2909-2917

Nelson DC, Williams CA, Farah BA, Shively JM (1989b) Occurrence and regulation of calvin cycle enzymes in non-autotrophic Beggiatoa strains. Arch Microbiol 151: $15-19$

Otte S, Kuenen JG, Nielsen LP, Paerl HW and 6 others (1999) Nitrogen, carbon, and sulfur metabolism in natural Thioploca samples. Appl Environ Microbiol 65:3148-3157

Sassen R, Roberts HH, Aharon P, Larkin J, Chinn EW, Carney R (1993) Chemosynthetic bacterial mats at cold hydrocarbon seeps, Gulf of Mexico continental slope. Org Geochem 20:77-89

Sassen R, MacDonald IR, Requejo AG, Guinasso NL, Kennicutt MC, Sweet ST, Brooks JM (1994) Organic geochemistry of sediments from chemosynthetic communities, Gulf of Mexico slope. Geo-Mar Lett 14:110-119

Sassen R, MacDonald IR, Guinasso NL Jr, Joye S and 5 others (1998) Bacterial methane oxidation in sea-floor gas hydrate: significance to life in extreme environments. Geology 26: 851-854

Sen Gupta BK, Platon E, Bernhard JM, Aharon P (1997) Foraminiferal colonization of hydrocarbon-seep bacterial mats and underlying sediment, Gulf of Mexico slope. J Foraminifer Res 27:292-300

Strohl WR, Schmidt TM (1984) Mixotrophy of the colorless, sulfide-oxidizing gliding bacteria Beggiatoa and Thriothrix. In: Stroh WR, Tounvinen $\mathrm{OH}$ (eds) Microbial chemoautrophy. Ohio State University Press, Columbus, p 79-95

Taylor CD, Wirsen CO (1997) Microbiology and ecology of filamentous sulfur formation. Science 277:1483-1485

Wirsen CO, Jannasch HW, Molyneaux SJ (1992) Results of studies concerning microbiota. In: MacDonald IR, Schroeder W (eds) Chemosynthetic ecosystems study interim report, Appendix A. US Dept. Interior, Minerals Management Service, Gulf of Mexico OCS Region, New Orleans, p A1-A14

Submitted: February 15, 2002; Accepted: December 10, 2002 Proofs received from author(s): April 25, 2003 